\title{
L'UNIVERSTTÉ DE PARIS
}

A L'ÉPOQTE

\section{DE LA DOMINA'TION ANGLAISE}

PAR

\section{CHARLES JOURDAIN}

Membre de l'Institut.

Extrait du Bulletin de l'Académie des Inscriptions et belles-lettres 6

\section{PARIS}

INPRIMERIE DE E. DONNAUD́

9, ROE Cassette, 9

1870 